DOI: $10.1515 / 1 p t s-2015-0006$

\title{
POTENTIAL OF VIRAC* RT-32 AND RT-16 ANTENNAS TO SERVE AS SATELLITE GROUND STATION
}

\author{
M. Bleiders, J. Trokss, M. Elerts \\ Engineering Research Instutute, Ventspils International Radio Astronomy Centre, \\ the Ventspils University College, \\ 101 Inzenieru Str., Ventspils, LV-3601, LATVIA
}

\begin{abstract}
The basic application of RT-32 and RT-16 parabolic antennas is radio astronomy observations, both the radio-telescopes have been upgraded with state-of-the art cryogenic receivers, and now a large-scale modernization of the infrastructure is underway. Since the radio-astronomical observations are not full-time activities, a research work has been done to clear up whether these antennas, besides the mentioned activities, can be used as a satellite ground station. The main goal of this added functionality is to make possible the use of the extremely high reception systems' figure-of-merit thus raising the satellite downlink data rates without increasing the on-board power consumption, which would be particularly important for developers of small satellites. In this paper, the progress in the research project is reported, which includes successful S-band satellite signal reception experiments and possible options as to integration of the related equipment into the system so that both functionalities could successfully coexist. Performance of the existing and the upgraded antenna positioning systems is estimated to determine if the latter are usable even for servicing low-Earth orbiting satellites. In addition, possible options are considered as to upgrading the system with automatic beam tracking capability, which would increase the antenna pointing accuracy even further.
\end{abstract}

Keywords: VIRAC, RT-32 and RT-16 parabolic antennas, satellite ground station.

\section{INTRODUCTION}

During the last few decades the satellite technologies have become much more accessible, especially with development of "nano" and "pico" satellites. As there always a compromise exists between the satellite on-board power consumption and the maximum error-free transmission data rate, small satellite possessors usually have to cope with slower data rates and split the already available data downlink among multiple passes in the low-Earth orbit (LEO) cases. One of the possibilities to overcome this difficulty is to increase the sensitivity of ground station's reception

${ }^{*}$ Ventspils International Radio Astronomy Center; Ventspils Starptautiskais radioastronomijas centrs 
system. This would make it possible not only to increase the data rate without increasing the power consumption, but also to reduce the weight and size of a satellite and even to make it feasible for using in higher orbits.

With their large apertures, VIRAC RT-32 and RT-16 parabolic antennas are great candidates for serving as a ground station with a highly sensitive reception system. It is obvious that the figure-of-merit of such a station would be high enough for communication with the smallest satellites, however in practice it is necessary to carry out research in order to understand how to integrate the satellite ground station's functionality into the existing system intended for astronomical activities. This would also make a better use of the available infrastructure, since the antennas are usually not loaded full time.

One of the ways to better understand how the additional functionality could coexist with the primary one and to reveal hidden problems is to carry out a practical experiment - in our case it was decided to try the signal reception from small LEO satellites. Also, in the cases of request from LEO satellite teams, performance of the antenna positioning system would be highly significant, so in such a test we can estimate it.

\section{LEO SATELLITE SIGNAL RECEPTION EXPERIMENT}

As the required data rate constantly increases, wider signal bandwidths are needed, so for the satellite-ground channels with increased data capacity higher carrier frequency bands (e.g. S- and C-band) are typically used. Decision was made to focus on the S-band, as it is relatively often used for small satellite downlinks and allows testing a system with signals from the satellites which are already in orbit. To do the reception test it was necessary to build an S-band frequency down converter (Fig. 1) for signals to be recorded using the available sets of software-defined radio (SDR) receivers.

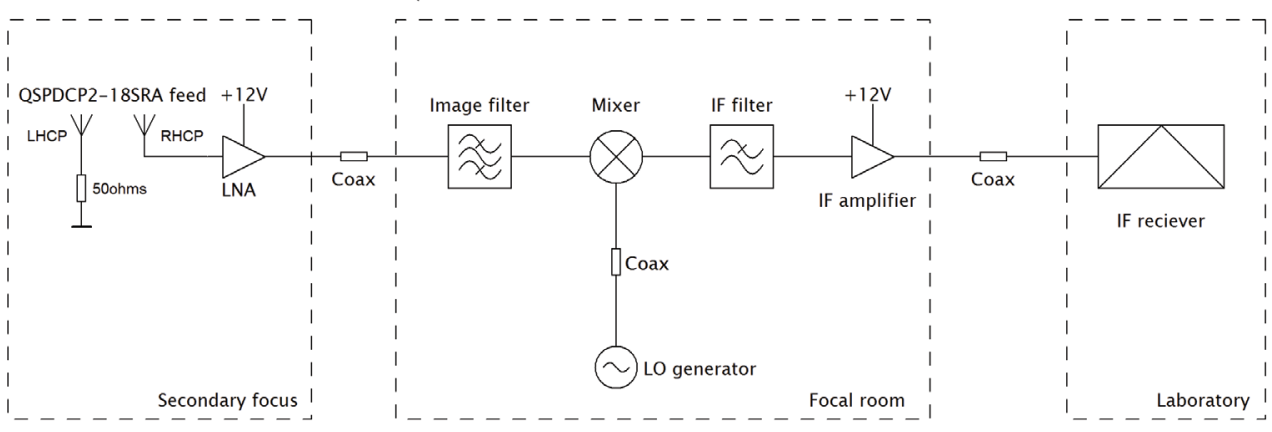

Fig. 1. Block diagram of S-band receiver.

For the initial tests, a sinuous type wideband QSPDCP2-18SRA feed antenna had been adopted and mounted on the secondary focus of RT-32 antenna. Since the main lobe taper of the feed was not optimal for the RT-32 secondary mirror configuration, additional measures were taken to significantly improve the reception. For example, an interdigital image signal filter was made for the use with S-band satellite signals between 2200 and $2300 \mathrm{MHz}$. The measured noise figure of the receiver (its block diagram is shown in Fig. 1$)$ was $\approx 1 \mathrm{~dB}(75 \mathrm{~K})$ including coaxial cable losses 
at the LNA output. The FUNcube Dongle Pro+ SDR was taken as an intermediate frequency signal receiver.

Reception tests were successful, and the signals from several satellites were received. For all calculations of the antenna local coordinates the orbital parameters of a convenient two-line element (TLE) were used. First tests were done without antenna steering, just with pointing the antenna at the apogee of satellite pass. After that, the reception in antenna tracking mode using the slow-motion drive was also tested. The spectrum of the received BRITE-PL LEO satellite signal is exemplified in Fig. 2 for the case of full pass.

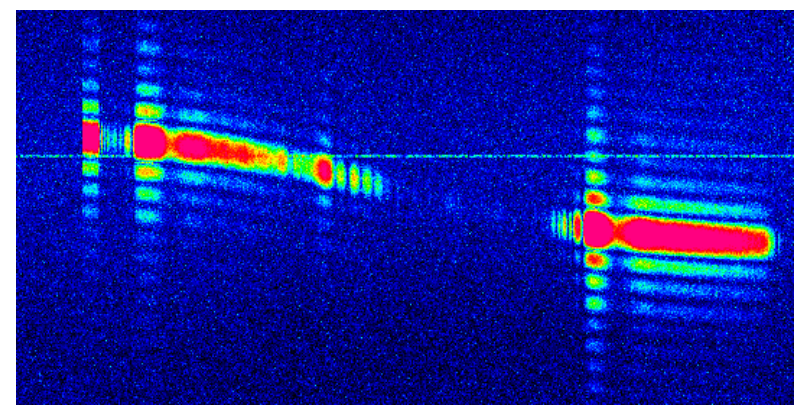

Fig. 2. Full pass recording of received BRITE-PL satellite signal (June 1, 2014). The maximum elevation of pass: $19.7^{\circ}$.

As seen in Fig.2, the strongest signal was received at the start and the end of pass, experiencing full signal loss in the middle of pass, since close to the apogee the slow-motion antenna drive mechanisms were unable to maintain the required tracking speed. Taking into account the relatively narrow half-power beamwidth of RT-32 (at S-band frequencies it is only $\approx 0.25^{\circ}$ ), it can be concluded that there are no significant pointing errors; therefore, the convenient open-loop tracking method based on the orbital model using TLE parameters can give a reasonable accuracy.

\section{PERFORMANCE OF THE ANTENNA STEERING SYSTEM}

To enable operation of the antennas as a satellite ground station, the accuracy and speed of their steering system is highly important. The rate of changes in azimuth and elevation as function of the maximum elevation of pass calculated for a typical polar LEO satellite is shown in Fig.3.

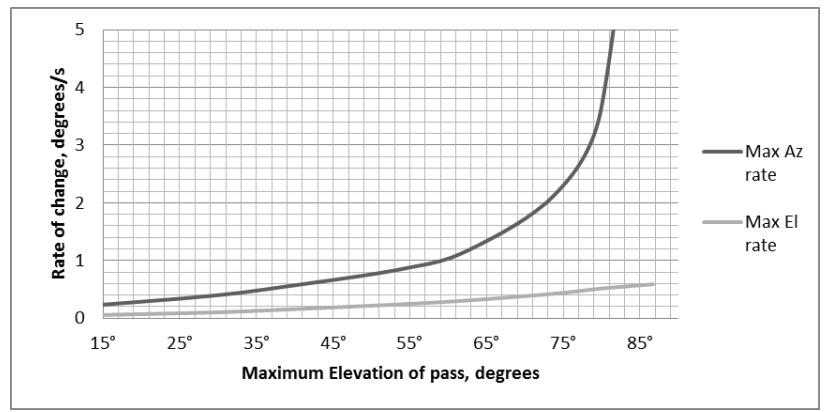

Fig.3. Rate of changes in azimuth and elevation depending on the maximum elevation of pass calculated for BRITE-PL LEO satellite (altitude of the orbit $\approx 700 \mathrm{~km}$ ). 
Currently, both RT-32 and RT-16 pointing systems incorporate slow and fast drives for the antenna azimuthal and elevation positioning with the corresponding maximum azimuthal/elevation angular speeds of $2 \%$ for RT-32 [1] and only $0.25 \% \mathrm{~s}$ for RT-16 [2], as its fast drive is not functioning. At these speeds the maximum elevation of a typical LEO satellite pass that antennas can support is $73^{\circ}$ for RT-32 and $20^{\circ}$ for RT-16. The tracking capability after renovation of the antenna drive system is to be improved and to reach the planned maximum speeds of at least $2.8 \%$ s for RT-32 and $5 \%$ s for RT- 16 , which would enable tracking LEO satellites with pass elevations of at least $77^{\circ}$ and $81^{\circ}$, respectively.

\section{APPLICATION OF WIDEBAND CRYOGENIC MICROWAVE RECEIVERS FOR FUNCTIONING OF THE SATELLITE GROUND STATION}

Recently, the VIRAC reception system has been upgraded with a wideband cryogenic receiver which covers frequencies within 4.5-8.8 GHz with the maximum noise temperature of $16 \mathrm{~K}$. The receiver has dual channels for LH and RH circularpolarized signals with a wideband feed horn specially optimized for illuminating the RT-32 and RT-16 secondary mirrors. Theoretically, such a receiver could be used for satellite signal reception; however, because of high gain (the average overall of 94 $\mathrm{dB})$ its dynamic range could be too narrow to receive relatively strong signals. In turn, this is perfectly usable in special cases - high-speed communication channels for power-limited satellites or small ones in high altitudes or even lunar orbits. For both reception systems the figure-of-merit $\mathrm{G} / \mathrm{T}_{\mathrm{s}}$ is estimated (Fig. 4).

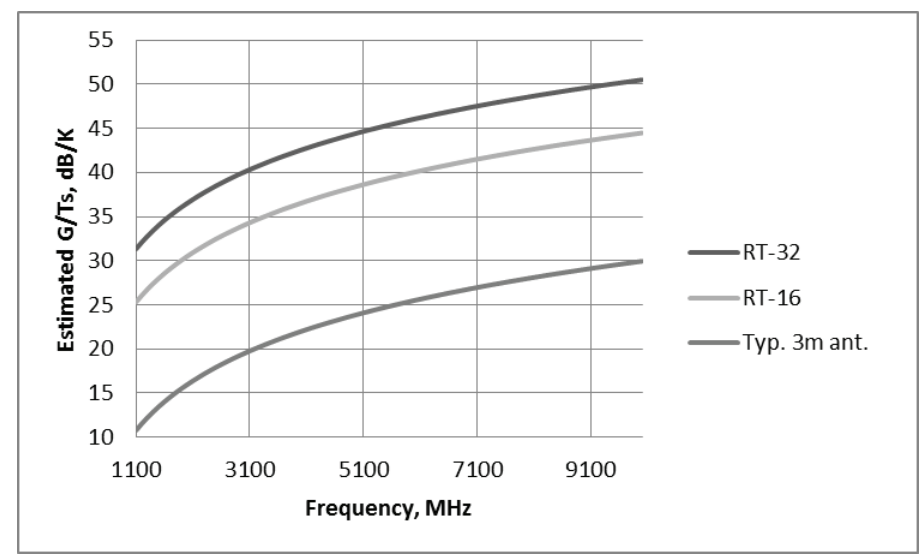

Fig.4. Estimated figure-of-merit of RT-32 and RT-16 reception systems compared with that of typical LEO base station using $3 \mathrm{~m}$ parabolic antenna [3].

Despite the receiver's broad bandwidth there still could be need for coverage of other bands, e.g. S-band and K-bands. To cover the required bands, additional receiving feeds are to be mounted; therefore, potential options have been considered as to their integration into the system without affecting the primary radio astronomy functionality. One of the solutions would be the location of additional feeds away from the primary focus point; however, this was not thoroughly examined, since theoretically the gain loss could be too high at short wavelengths [4]; besides, mounting the receiver would be more difficult. In [5] it is shown that even at $\lambda=0.35 \mathrm{~mm}$ the 
gain degradation of a Cassegrain antenna with effective ratio $f / D=6.1$ is relatively small with laterally offset feed at the secondary focus. Therefore, we have carried out research and appropriate simulations in order to understand how the performance of RT-32 is affected in the mentioned offset case. In Fig.5 the simulation results are shown that are calculated with GRASP SE software at the wavelength of $13 \mathrm{~cm}$.
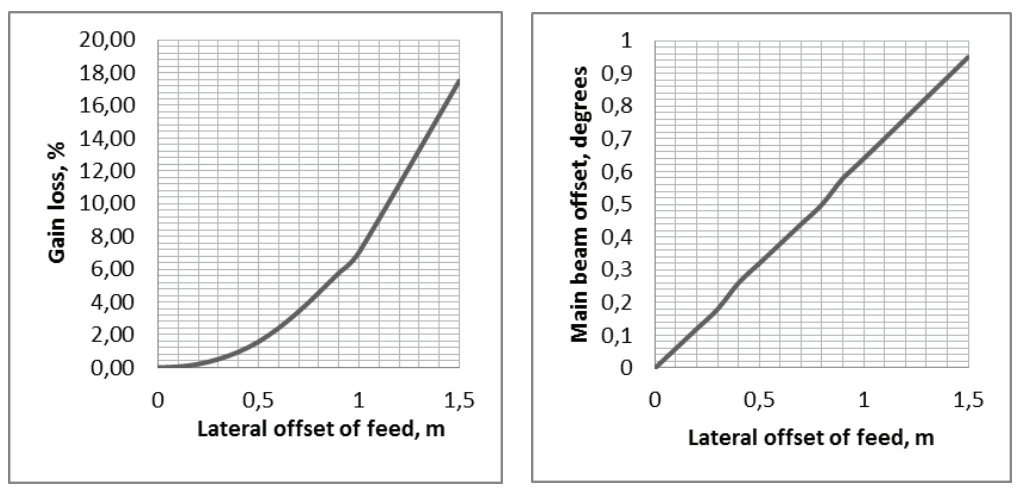

Fig. 5. Gain degradation and beam offset with lateral feed offset calculated for RT-32 at $\lambda=13 \mathrm{~cm}$.

From the results obtained it can be inferred that even though the beam is offset, the HPBW of the main beam has broadened (which though can be a benefit for satellite tracking) and the orthogonal polarization response has increased, the gain loss is relatively small, maintaining a large figure-of-merit of the system. Therefore, this can be considered as one of the solutions, with the results forming basis for experimental verification.

\section{RECONSTRUCTION}

Currently, the VIRAC antenna infrastructure undergoes large-scale reconstruction; in addition to the mentioned upgrades of receivers and antenna drive system, other mechanical, electrical and control systems will also be modernized. Supporting structures of RT-32 dish surface will be restored, and the surface of RT-16 will be replaced with a completely new carbon fibre composite, significantly decreasing its weight and thereby the tracking agility of antenna. The accuracy of position sensors will be increased to at least 2.5 " for each axis, and a modern control and monitoring system with remote control and increased safety will be installed. To ensure uninterruptable operation, the system will be equipped with backup power supplies.

Regarding the increase in the pointing accuracy, the methods have been considered that relate to the closed loop beam tracking using the power of received signal as feedback information. Step-track or mono-pulse based solutions would considerably reduce the beam pointing inaccuracies the causes of which are difficult to simulate and predict - e.g. wind influence and inaccurate calculations of the satellite orbital position.

\section{CONCLUSIONS}

The results of research show that progress is achieved in the integration of small satellite ground station functionality into the existing VIRAC RT-32 and RT-16 antenna system which was primarily intended for radio astronomy. Successful ex- 
periments on LEO satellite signal reception allow the performance estimation of the existing system, showing that a convenient open-loop tracking method based on the orbit prediction model using TLE parameters can give reasonable accuracy without significant pointing errors.

The new cryogenic receiver system effectively increases the figure-of- merit of a potential satellite ground station and allows increasing significantly the errorfree data rate in downlink channels exploited by small satellite possessors.

Simulations of laterally displaced feeds at the secondary focus show that the gain loss is here small, which means that the proposed solution can be used in case of demand for additional frequency bands.

Modernization of both antenna drive systems provides a higher pointing speed of antennas, which ensures communication at high elevations of LEO satellites passes.

\title{
ACKNOWLEDGEMENT
}

The presented $R \& D$ as part of the project No. L-KC-11-0006 is funded by the European Regional Development Fund.

\section{REFERENCES}

1. A. Balkavs, Ventspils radiotelescopes: History, Parameters, Possibilities, Baltic Astronomy, vol. 5 (1996)

2. V. Bezrukovs, A. Berzins, A.Lesins, G. Gaigals, J. Trokss: Starting-up the Irbene 16-m fully steerable parabolic antenna for radioastronomic observations, Latvian journal of physics and technical sciences 1 (2011)

3. M. Fischer: Multi-Mission Satellite Ground Station for Education and Research, Institute of Telecommunications (2012)

4. D. S. Evans, G. R. Jessop: VHF/UHF Manual, $3^{\text {rd }}$ edition, p. 8.53. - 8.54., ISBN 0-900612-312 (1979).

5. B. Shillue: Gain Degradation in a Symmetrical Cassegrain Antenna Due to Laterally Offset Feeds, MMA Memo 175 (1997).

\section{VSRC* ANTENU RT-32 UN RT-16 IZMANTOŠANAS IESPĒJAS SATELİTU KOMUNIKĀCIJAS ZEMES STACIJAS PIELIETOJUMIEM}

\author{
Bleiders, J. Trokšs, M. Ēlerts
}

K ops a vi $1 \mathrm{kums}$

Radioteleskopu RT-32 un RT-16 parabolisko antenu pamatpielietojums ir saistīts ar radioastronomiskajiem novērojumiem, abi radioteleskopi ir papildināti ar unikāliem kriogēniem mikroviḷnu uztvērējiem, paralēli tiek veikta vērienīga infrastruktūras modernizācija. Tā kā radioastronomiskie novērojumi nenotiek nepārtraukti, tika veikts pētîjums, lai noskaidrotu, vai bez radioastronomisko datu uztveršanas minētās antenas darbināmas arī kā satelīkomunikāciju zemes staci- 
jas. Šādas papildus funkcionalitātes galvenais mērķis ir izmantot esošo uztverošo sistēmu izcilos parametrus un nodrošināt iespēju palielināt satelîtu lejupraides datu plūsmas àtrumu, nepalielinot to jaudas patērinu, un tas varētu būt saistoši mazo satelītu iekārtu izstrādātājiem un ražotājiem. Rakstā aplūkoti mazo satelītu pārraidīto signālu uztveršanas eksperimenti S- diapazonā, kā arī analizēti varianti satelītsignālu uztveršanas aparatūras integrācijai esošajās sistēmās, nodrošinot abu pielietojumu sekmīgu līdzāspastāvēšanu. Darbā sniegts pašreiz lietoto un modernizācijas gaitā veidojamo antenu pozicionēšanas sistēmu parametru novērtējums nolūkā noskaidrot to pielietojamību satelītu - sevišķi Zemei tuvās orbītās esošu - komunikācijas kanālu apkalpošanai. Tiek analizētas iespējas papildināt sistēmas funkcionalitāti ar automatizētu sekošanu satelītu orbitālajai kustībai, tādējādi paaugstinot antenas orientēšanas precizitāti.

12.12.2014. 